\title{
A MODEL OF THE ORGANIZATIONAL AND ECONOMIC MECHANISM FOR ADOPTING AND IMPLEMENTING THE ISLAMIC INSURANCE IN RUSSIA
}

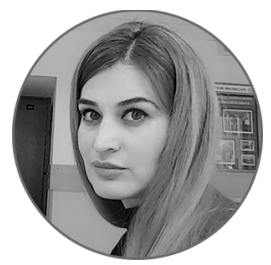

Article history:

Received 16 March 2016 Received in revised form 17 April 2016 Accepted 16 May 2016 Translated 8 August 2017 Available online 15 September 2017

JEL classification: G22

\author{
Madina M. MAGOMADOVA
}

Chechen State University, Grozny, Chechen Republic, Russian Federation

madina.magomadova@mail.ru

Keywords: family takaful, model, mechanism, non-governmental pension fund, insurance system

\begin{abstract}
Importance Considering the challenges of recent years (political isolation, economic sanctions), Russia has to revisit the future development of entire sectors and its national strategy without receding, however, from the market economy principles. Those challenges turned the spotlight onto the financial system and insurance sector, in particular. Therefore, the takaful insurance and its types become an important financial institution.

Objectives I design an organizational and economic mechanism to introduce and implement the family takaful in Russia based on non-governmental pension funds.

Methods I apply methods of logical and comparative analysis to detect factors, advantages, shortcomings and problems determining how exactly the family takaful can be implemented in Russia.

Results The paper presents basic components of the organizational and economic mechanism of the family takaful implementation in Russia, underpins the need for its development, specifies its nature and sequence of actions to introduce the Islamic insurance in Russia. I offer a model of the organizational and economic mechanism for implementing the Islamic insurance in Russia and define its constituents.

Conclusions and Relevance The offered constituents of the organizational and economic mechanism represent sophisticated scientific and methodological tools for adopting the Islamic insurance in Russia and specify the key aspects of its functioning, including its tasks and objectives, participants, targets, principles and rules.
\end{abstract}

(c) Publishing house FINANCE and CREDIT, 2016

The editor-in-charge of this article was Irina M. Komarova

Authorized translation by Irina M. Komarova

Interlaced with historical and political factors, Russia's multiconfessionalism, on the one hand, and democratic vector of the State, on the other hand, request such economic policies that would meet expectations and needs of representative social layers. Although Russia is promulgated as the secular State in one of the fundamental clauses of the national constitution (Article 14 of the Constitution of the Russian Federation), with religious associations being separated from the State, fundamental principles of various confessions can but influence economic and market

${ }^{\dagger}$ For the source article, please refer to: Магомадова М.М. Модель организационно-экономического механизма внедрения и реализации исламского страхования в России. Финансы и кредит. 2016. № 22. С. 40-50. relations. Classic authors in economics (for example, M. Weber [1]) and contemporary scholars ${ }^{1}$ delved into the way the religion and economy might influence one another and interact [2-4].

Furthermore, as stated in some significant researches, the religion tends to have a positive effect on the economy ${ }^{2}$.

${ }^{1}$ Kubon-Gilke G. [Zum Zusammenhang von Ökonomie und Religion]. Vestnik Kostromskogo gosudarstvennogo universiteta im. N.A. Nekrasova = Bulletin of Kostroma State University, 2007, vol. 13, no. 2, pp. 188-194. (In Russ.)

${ }^{2}$ Plyasovskikh A. Vliyanie khristianstva na ekonomicheskoe razvitie stran, ili o natsional'noi idee [An impact of the Christianity on the economic development of nations, or the national idea for Russia]. URL: http://www.nideya.narod.ru/razdel4.htm (In Russ.) 
For the recent years researches have been more actively exploring whether some Islamic principles are implementable in certain economic tenets. According to theoretical views of the Islamic economic scholars, social equity and fairness are one of the crucial principles of economic relations, protecting the right to equal allocation of resources.

Nowadays, Islamic principles have an impact on economic relations in various countries worldwide, piercing business practices, fiscal and tax policies, management in sponsorship and charity, insurance, etc.

Ethnic Muslims account for about 20 million people out of over 146 million of people constantly residing in Russia, according to different estimates ${ }^{3}$. Although the Russian Muslims have different commitment to the Islamic principles and laws, Russia sees a growing need in integrating certain financial constructs into the national system of law. The takaful, the Islamic approach to insurance, has become one of such constructs. As proved in my previous surveys in one of the regions with the prevailing Muslim population, this mechanism is important for Russia. About 30 percent of respondents, who did not have a voluntary insurance policy, mentioned the religious noncompliance as one of the reasons.

Thus, under the current circumstances, it is necessary to create scientific and methodological conditions for implementing the Islamic insurance in the Russian system of economic relations.

This research devises an organizational and economic mechanism for adopting and implementing the family and personal takaful in Russia through non-governmental pension funds.

The research pursues the following objectives:

- specifying the substance of takaful;

- determining constituents of the organizational and economic mechanism for the Islamic insurance;

- devising a model of the organizational and economic mechanism for adopting and implementing family and personal takaful plans in Russia through non-governmental pension funds;

\footnotetext{
${ }^{3}$ The number of population.

URL: http://www.gks.ru/free_doc/new_site/population/demo/demo11.xls (In Russ.)
}

- disclosing the substance of key components in the model.

Before unveiling the takaful substance, I examine its principles, aspects and distinctions. As Article 2 of Shariah Standard 26 describes the difference between the conventional insurance and takaful, the conventional insurance implies profit to be derived from insurance deals, which are exposed to uncertainty (al-gharar) and other activities condemned by the Shariah, such as usury (riba), gambling (al-maisir), etc. That is why the Shariah denies the conventional insurance based on commercial terms. The paragraphs below review these restrictions in more detail.

According to experts in the Islamic law, there are several types of uncertainty:

1. Neither party to an insurance transaction is cognizant of the probability of an insurance premium.

2. Certain insurance schemes fail to provide clarity concerning the amount of an insurance premium.

3. The insured party does not know whether the insurer has a relevant amount for the insurance coverage in case of an insurable event.

4. The contract does not stipulate the time of the insurable occurrence.

5. The policy holder is unsure that his/her payment will be used for the Shariah-permitted transactions, meaning than they may be involved into a forbidden activity (haram), in addition to the uncertainty ${ }^{4}$ [5].

Uncertainty stems from operational and information difficulties and relates to any ambiguity or contingency of contractual terms, which arise due to unavailable data or control under the contract. If these factors are in place, it makes the contract null and void in terms of the Islamic laws.

As for the usury, or riba, it does exist in the conventional insurance. For example, it arises when equity and claims reserves are invested in such assets as bank deposits or assets relating to the Islam-banned activities (production of tobacco, alcohol, etc.). However,

\footnotetext{
${ }^{4}$ Haram (Arab. حرام, cognate harem) means actions prohibited by the Shariah. Haram is an antagonist of halal. For example, pork is haram, while lamb meat is halal as it is slaughtered with the name of Allah being pronounced.
} 
the insured party may decline such assets while making an investment, if needed.

As for the al-maisir ban (business gambling means an excessively risky undertaking in this context) and countering it, the Central Bank of Russia, as the insurance market regulator, controls the ratio of the policy holder's equity and obligations under the Rules approved by Instructions of the Central Bank of Russia of July 28, 2015 № 3743-У.

As stated above, I formulate the key principles and aspects of takaful ${ }^{5}[6]$ :

- there shall not be excessive uncertainty since takaful participants uphold their entitlement for takaful funds and gain (income) from investment and insurance transactions;

- risks of insurance participants should be secured with guarantees since takaful, first of all, envisages that contracting parties can act as guarantors and guarantees;

- there shall be a special mechanism for distribution of profit among takaful-holders and the company managing takaful funds as reviewed hereinafter;

- a special authority (the Shariah supervisory board) shall control takaful operations;

- the utmost good faith shall be a guiding principle as a fundamental law, which all contracting parties shall adhere to:

- policy holders shall be allowed to manage the takaful company;

- there is a distinction in inheriting the entitlement for an insurance premium. All lawful heirs of the policy holder (the takaful participant) are entitled for the insurance premium, notwithstanding the appointed beneficiary.

These principles and aspects allow revealing the economic substance of takaful and formulating my own definition in line with the terminology circulating in the Russian laws on insurance.

\footnotetext{
${ }^{5}$ Magomadova M.M. [Takaful as a tool for developing the insurance market of the region]. Sborniki konferentsii NITS Sotsiosfera $=$ Conference Proceedings of the Science Publishing Centre Sociosphere, 2015, no. 36, pp. 51-54. (In Russ.)
}

Takaful constitutes the redistribution relations based on mutual assistance and aid so to avoid adverse events (risks) when takaful participants voluntarily contribute their funds to a special-purpose pool and intend to get reimbursements in case of unfavorable (insurable) events and gain from pooled fund investment provided they manage the pool on their own or through a hired managing company on the Shariah principles. V.O. Fedorovich offered a tiered hierarchical system of key interlinked constituents and groups (agents, targets, principles, methods, tools, etc.) and methods of their interaction, including the integration and disintegration, which, afoot or subsequently, harmonize economic relationships (interests) of the State, business and public structures. In my opinion, Fedorovich's system is the best to address objectives of this research [7].

The organizational and economic mechanism for adopting and implementing the family takaful scheme shall mean a system of mutual relations among participants of the financial system, including the insurance market, management methods, rules, principles, functions, which address goals and objectives of the Islamic insurance.

Analyzing the main approaches to formulating the organizational and economic mechanism [8-10], it is possible to conclude that the mechanism is composed of management agents, management targets, goals and objectives to be attained with the mechanism, practical principles of the mechanism, participants' duties, applicable methods and tools to address objectives of the mechanism, interaction factors of agents.

Considering the current insurance system in Russia [11-13] and the possibility of supplementing it with the Islamic insurance mechanism, I can outline a general sequence of steps that shall be undertaken to integrate the organizational and economic mechanism of takaful (Fig. 1).

The insurance system and legal framework, the way they are existing in Russia, do not necessitate a separate regulatory document in order to completely implement the Islamic insurance scheme. The existing legislation on insurance ${ }^{6}$ might be edited and amended from the following perspectives:

\footnotetext{
${ }^{6}$ Law of the Russian Federation On Setting Up Insurance Practices in the Russian Federation of November 27, 1992 № 4015-1.
} 
- supplementing legislative principles with new business and legal forms applicable to the specifics of takaful operators;

- setting a legal environment for the Islamic insurance as part of the mechanism of non-governmental pension funds.

It is reasonable to clarify the structural content of the organizational and economic content of the Islamic insurance so to specify the proposed sequence of steps to adopt and implement it. Based on the takaful specifics [14] and the said constituents of the organizational and economic mechanism, I can frame the structure of the organizational and economic mechanism for adopting and implementing the Islamic insurance in Russia (Fig. 2).

I proceed with scrutinizing the substance of each constituent in the mechanism. The purpose of the mechanism considerably carves what other constituents imply, setting the effective and Shariah-compliant system of the Islamic insurance in Russia. This goal entails the following interim objectives to be met in setting up the organizational and economic mechanism:

- choosing the Islamic insurance participants and assigning duties to each of them;

- articulating practical principles and rules for the mechanism;

- determining methods, tools and approaches to implement the mechanism, both organizational and economic ones;

- laying the groundwork for running various business models of the Islamic insurance.

This scheme nominates the principal agents of the mechanism:

1) takaful operators or insurers are entities that are incorporated as joint-stock companies or cooperative insurance vehicles to deliver the Islamic insurance services [15];

2) public regulators are authorized governmental bodies in charge of the regulatory compliance of takaful operations, and improvement of the underlying laws;
3) institutions for support and development are non-governmental entities (usually non-profit) that develop and promote the Islamic insurance in Russia. This party can be represented with a union (association) of takaful operators of Russia.

The proposed mechanism puts the family insurance scheme as a target of management. The family takaful mainly has a saving function and provides for the issue of various policies, which, to a certain extent, correspond with conventional insurance.

I suppose, the system and principles of non-governmental pension funds would be the most appropriate as the groundwork for implementing the organizational and economic mechanism of the Islamic insurance. I opt for non-governmental pension funds as possible participants of the Islamic insurance mechanism since they are very akin to the takaful specifics, including the takaful focus on savings, rather than insurance only. As another factor that juxtaposes non-governmental pension funds with requirements of the Islamic insurance, personal insurance in Russia is mainly effectuated through pension insurance instruments. This distinctive feature of the Russian system, that engenders inter alia distrust of the existing schemes of personal voluntary insurance, bolsters a growing potential of the Islamic insurance in Russia.

Any organizational and economic mechanism should draw upon principles and policies that considerably determine the substance of its constituents, including functions and tools the Islamic insurance participants apply. I suggest splitting the entire population of the Islamic insurance principles in two groups:

1) generic principles of the Islamic insurance system as part of the national insurance system, including [16]:

- the existence of an insurable interest;

- risk insurability;

- equivalence;

- mutual trust of participants;

- adequacy of reimbursement in relation to factual losses;

- cause-and-effect relationship between the loss and the trigger; 
- contribution;

2) particular (specific) principles of the Islamic insurance system that originally stem from its religious background, including:

- zero uncertainty;

- voluntary will;

- the Shariah-permitted income;

- risk sharing.

These principles outline the rules for the organizational and economic mechanism. The rules shall be enshrined in laws and internal regulations of takaful operators.

Considering the goals, objectives, principles, targets and rules of the organizational and economic mechanism of the Islamic insurance in Russia, respective participants choose appropriate methods and tools to put this mechanism into practice. Whereas there is a plethora of methods and tools to manage and promote the Islamic insurance, it is reasonable to consider key duties and functions of the respective participants (Table 1).

Whereas Russia lacks a robust legal, organizational and economic framework for implementing the Islamic insurance, it significantly obstructs its effective and productive development. The constituents of the organizational and economic mechanism I propose in this research - constitute a comprehensive set of research and methodological tools to implement the Islamic insurance in Russia. It envisages key aspects of its application in Russia in terms of goals, objectives, participants, targets, principles and rules. I admit the complexity of the organizational and economic mechanism of the Islamic insurance as well as the difficulty to unfold this mechanism in detail within this particular research. Hence, each of the given constituents needs to be specified and assessed for its feasibility in the Russian systems of law and insurance.
Therefore, future researches shall pursue the following objectives:

- providing a detailed view of organizational and legal regulations governing the Islamic insurance in Russia;

- detailing functions of the Islamic insurance participants, i.e. governmental regulators, takaful operators and institutes for developing and supporting this insurance market;

- specifying organizational aspects of the interaction among the Islamic insurance participants.

Russia's insurance market may be reasonably supplemented with takaful companies due to the following reasons:

- takaful operators carry out their activity in Russia without violating the existing laws on insurance. The would be customers - over 20-25 million of ethnic Muslims - may be involved into insurance deals;

- many trade and financial partners of Russia from the Middle East are reluctant to invest in various mutually beneficial projects due to instability of the economic situation and bad faith in the Russian counterparts;

- Russia's insurance market demonstrates high levels of competition. The market will be diversified after takaful operators offer their schemes and plans, thus supporting the development of the insurance in Russia;

- it is very relevant and opportune to examine various aspects of the takaful insurance and its application in the Russian practice. The takaful insurance extends business and legal forms adopted in the Russian insurance market in accord with the respective trends worldwide. This will also increase the variety of insurance products since they will include the insurance against the reimbursement risk upon the insurable occurrence. It is expected to stabilize the social situation. 


\section{Table 1}

Functions of parties to the Islamic insurance system

\begin{tabular}{|c|c|}
\hline Islamic Insurance Participant & Functions \\
\hline $\begin{array}{l}\text { Governmental regulators } \\
\text { (represented by authorized } \\
\text { governmental bodies) }\end{array}$ & $\begin{array}{l}\text { Licensing of takaful operators. } \\
\text { Compliance control over the consumption of the Islamic financial services. } \\
\text { Control over performance risks of takaful fund operators. } \\
\text { Regulation, control and oversight over insurance and investment deals }\end{array}$ \\
\hline Takaful companies & $\begin{array}{l}\text { 1. Protective (saving) functions: } \\
\text { - assessment of insurance risks; } \\
\text { - insurance reimbursements; } \\
\text { - reallocation of funds among participants of the takaful scheme and others. } \\
\text { 2. Accumulative functions: } \\
\text { - accumulating profit of takaful-holders from investment of the takaful funds; } \\
\text { - distribution of profit among takaful-holders. } \\
\text { 3. Preventive functions: } \\
\text { - assessment of insurance risks; } \\
\text { - accrual of claims reserves (as part of takaful funds), etc. } \\
\text { 4. Investment functions [17]: } \\
\text { - charging fees to takaful funds; } \\
\text { - distribution of funds; } \\
\text { - investing pooled funds for halal purposes; } \\
\text { - acceptance of contributions to the takaful fund from takaful operators. } \\
\text { 5. Organizational functions: } \\
\text { - preparation of contracts with individuals and legal entities and the issuance of personal takaful policies; } \\
\text { - regional promotion of the Islamic insurance services; } \\
\text { - arrangement of compensation benefits to be paid under personal insurance plans; } \\
\text { - arrangement of earnings to be paid under family insurance plans; } \\
\text { - arrangement of the acceptance of insurance contributions, etc. }\end{array}$ \\
\hline $\begin{array}{l}\text { Supporting and developing } \\
\text { institutions }\end{array}$ & $\begin{array}{l}\text { Compliance control of insurance products with the Shariah requirements }[18,19] \text {. } \\
\text { Professional advancement of takaful operators' staff on gratuitous and tuition-fee basis. } \\
\text { Setting up standards of takaful operators' financial activities and participating in their implementation. } \\
\text { Liaison with authorized governmental bodies for legal and organizational alignment of the takaful insurance in } \\
\text { line with the Russian legislation. } \\
\text { Promotion of the Islamic insurance at the federal and regional level, etc. }\end{array}$ \\
\hline
\end{tabular}

Source:Authoring

Please cite this article as: Magomadova M.M.A Model of the Organizational and Economic Mechanism 


\section{Figure 1}

The algorithm for integrating and implementing the organizational and economic mechanism of the Islamic insurance

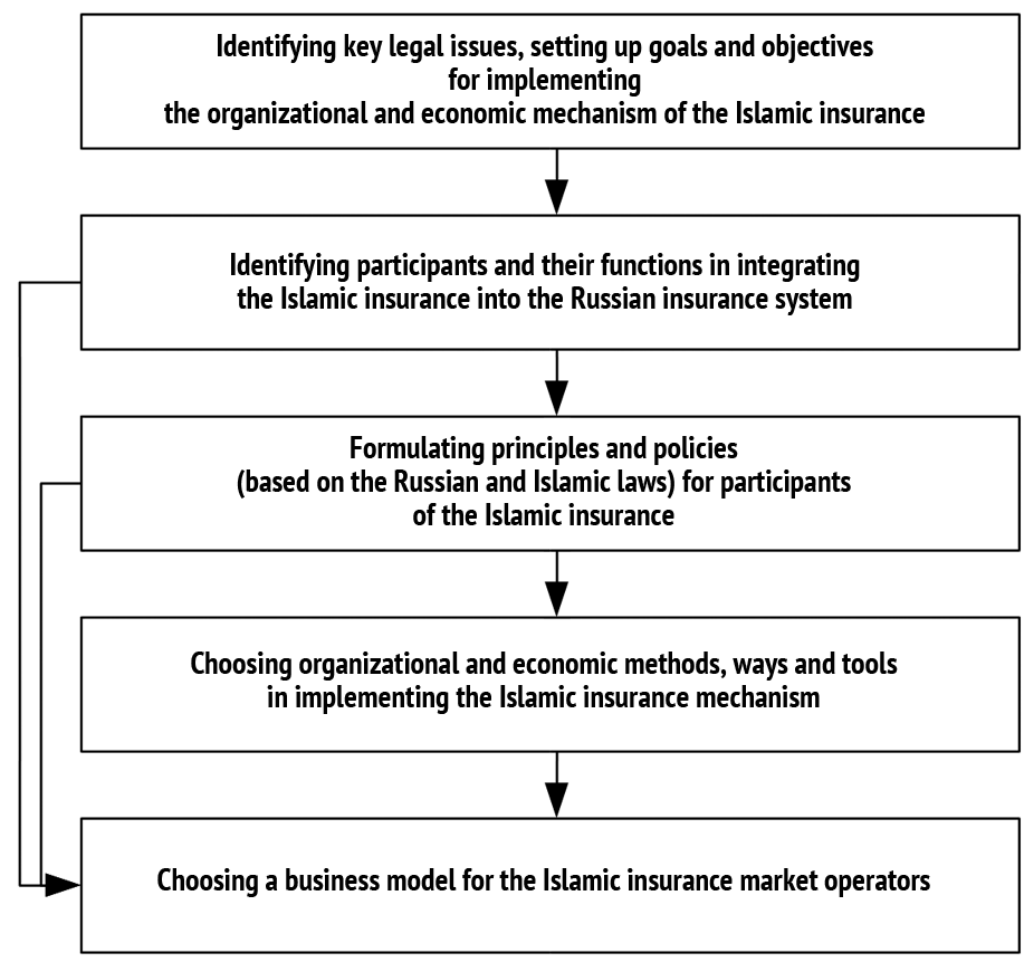

Source:Authoring 


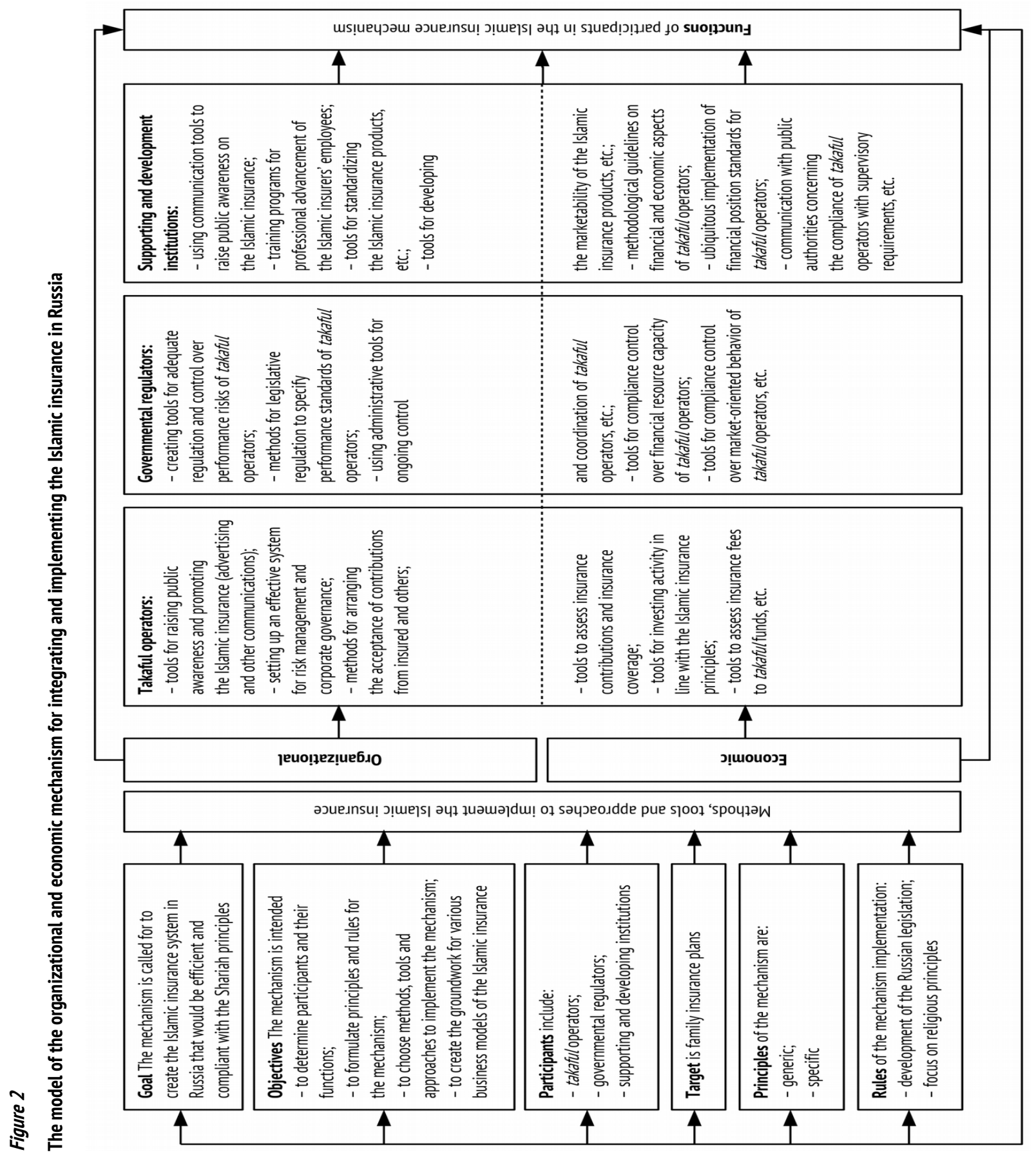

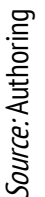

Please cite this article as: Magomadova M.M.A Model of the Organizational and Economic Mechanism

for Adopting and Implementing the Islamic Insurance in Russia. Digest Finance, 2017, vol. 22, iss. 3, pp. 346-355.

https://doi.org/10.24891/df.22.3.346 


\section{References}

1. Weber M. Izbrannoe. Obraz obshchestva [Gesammelte Aufsätze zur Soziologie und Sozialpolitik]. Moscow, Yurist Publ., 1994, 704 p.

2. Alekseeva M.S. [Ethics, religion and economy: Interrelation in the context of current social and economic issues]. Vestnik Sibirskogo universiteta potrebitel'skoi kooperatsii = Bulletin of Siberian University of Consumer Cooperation, 2014, no. 1, pp. 28-35. (In Russ.)

3. Nesprava V.N. [Influence of religion on condition and growth rates of the national economy]. Ekonomicheskii nobelevskii vestnik = Nobel Economic Herald, 2012, no. 1-2, pp. 265-270. (In Russ.)

4. Koslowsky P. Printsipy eticheskoi ekonomii [Prinzipien der Ethischen Ökonomie. Grundlegung der Wirtschaftsethik]. St. Petersburg, Ekonomicheskaya shkola Publ., 1999, 344 p. (In Russ.)

5. Magomadova M.M. Implementation of Takaful Insurance System in the Russian Federation and its Future. Middle-East Journal of Scientific Research, 2013, vol. 16, iss. 9, pp. 1178-1182.

6. Magomadova M.M. [The functions of a takaful in modern conditions]. Teoriya i praktika obshchestvennogo razvitiya = Theory and Practice of Social Development, 2015, no. 16. (In Russ.)

7. Fedorovich V.O. [The composition and structure of the organizational and economic mechanism for managing the property assets of large industrial corporations]. Sibirskaya Finansovaya Shkola = Siberian Financial School, 2006, no. 2, pp. 106-115. (In Russ.)

8. Goloshchapova T.V. [Essence and content of the economic-organizing mechanism of enterprise operating]. Vestnik Povolzhskogo gosudarstvennogo universiteta servisa = Bulletin of Volga Region State University of Service, 2006, no. 1, pp. 66-72. (In Russ.)

9. Izmalkov S.B., Sonin K.I., Yudkevich M.M. [Theory of mechanism design]. Voprosy Ekonomiki, 2008, no. 1, pp. 4-26. (In Russ.)

10. Lomakina I.L. [Methodological principles for setting up an organizational and economic mechanism for corporate governance]. Trudy Dal'nevostochnogo gosudarstvennogo tekhnicheskogo universiteta = Proceedings of Far Eastern State Technical University, 2007, no. 146, pp. 185-188. (In Russ.)

11. Taimaskhanov Kh.E., Tsakaev A.Kh. [The market of insurance services in the Chechen Republic: risks and opportunities for growth]. Strakhovoe delo = Insurance Business, 2014, no. 3, pp. 52-59. (In Russ.)

12. Ulybina L.K., Okorokova O.A., Van'yan G.A. [Insurance market of Russia: Assessment of indicators and development prospects]. Ekonomika i predprinimatel'stvo = Journal of Economy and Entrepreneurship, 2013, no. 7, pp. 64-68. (In Russ.)

13. Natkhov T. [Market of insurance in Russia: Major tendencies and problems of development]. Voprosy Ekonomiki, 2006, no. 12, pp. 115-127. (In Russ.)

14. Fukina S.P. [Features of the organization of Islamic insurance and prospects of its introduction into the insurance market of Russia]. Vestnik Astrakhanskogo gosudarstvennogo tekhnicheskogo universiteta = Vestnik of Astrakhan State Technical University. Series: Economics, 2014, no. 1, pp. 108-116. (In Russ.)

15. Al-Ghadyan A.A. Insurance: The Islamic Perspective and Its Development in Saudi Arabia. Arab Law Quarterly, 1999, vol. 14, iss. 4, pp. 179-184. URL: https://doi.org/10.1163/026805599125826534

Please cite this article as: Magomadova M.M.A Model of the Organizational and Economic Mechanism 
16. Nemtseva Yu.V., Matveev A.L. [Risk-based approach to the management of insurance companies' investment activities]. Rossiiskoe predprinimatel'stvo = Russian Journal of Entrepreneurship, 2015, vol. 16, no. 8, pp. 1129-1144. URL: https://doi.org/10.18334/rp.16.8.194 (In Russ.)

17. Umarov Kh.S. [On Takaful Islamic insurance]. Strakhovoe delo = Insurance Business, 2014, no. 4, pp. 47-53. (In Russ.)

18. Archer S., Karim R.A., Nienhaus V. Takaful Islamic Insurance: Concept and Regulatory Issues. Wiley, 2009,300 p.

\section{Conflict-of-interest notification}

I, the author of this article, bindingly and explicitly declare of the partial and total lack of actual or potential conflict of interest with any other third party whatsoever, which may arise as a result of the publication of this article. This statement relates to the study, data collection and interpretation, writing and preparation of the article, and the decision to submit the manuscript for publication. 